\title{
Ecophysiological Traits of Terrestrial and Aquatic Carnivorous Plants: Are the Costs and Benefits the Same?
}

\section{Citation}

Ellison, Aaron M. and Lubomír Adamec. Forthcoming. Ecophysiological traits of terrestrial and aquatic carnivorous plants: are the costs and benefits the same? Oikos.

\section{Published Version}

http://onlinelibrary.wiley.com/journal/10.1111/\%28ISSN\%291600-0706

\section{Permanent link}

http://nrs.harvard.edu/urn-3:HUL.InstRepos:4777759

\section{Terms of Use}

This article was downloaded from Harvard University's DASH repository, and is made available under the terms and conditions applicable to Other Posted Material, as set forth at http:// nrs.harvard.edu/urn-3:HUL.InstRepos:dash.current.terms-of-use\#LAA

\section{Share Your Story}

The Harvard community has made this article openly available. Please share how this access benefits you. Submit a story.

Accessibility 
1 Ecophysiological traits of terrestrial and aquatic carnivorous plants: are the costs and

2 benefits the same?

3

4 Aaron M. Ellison* and Lubomír Adamec

5

6 A. M. Ellison (aellison@fas.harvard.edu), Harvard Forest, Harvard University, 324 North Main

7 Street, Petersham, Massachusetts 01366, USA. - L. Adamec, Institute of Botany, Academy of

8 Sciences of the Czech Republic, Section of Plant Ecology, Dukelská 135, CZ-379 82 Třebon̆,

9 Czech Republic.

10

11

Both authors contributed equally to this work

12

13 *Address all correspondence to AME.

14 E-mail: aellison@ fas.harvard.edu

15 Tel: +1-978-756-6178

16 Fax: +1-978-724-3595

17

18

14 March 2011

19 
21 Identification of trade-offs among physiological and morphological traits and their use in cost-

22 benefit models and ecological or evolutionary optimization arguments have been hallmarks of

23 ecological analysis for at least 50 years. Carnivorous plants are model systems for studying a

24 wide range of ecophysiological and ecological processes and the application of a cost-benefit

25 model for the evolution of carnivory by plants has provided many novel insights into trait-based

26 cost-benefit models. Central to the cost-benefit model for the evolution of botanical carnivory is

27 the relationship between nutrients and photosynthesis; of primary interest is how carnivorous

28 plants efficiently obtain scarce nutrients that are supplied primarily in organic form as prey,

29 digest and mineralize them so that they can be readily used, and allocate them to immediate

30 versus future needs. Most carnivorous plants are terrestrial - they are rooted in sandy or peaty

31 wetland soils - and most studies of cost-benefit trade-offs in carnivorous plants are based on

32 terrestrial carnivorous plants. However approximately $10 \%$ of carnivorous plants are unrooted

33 aquatic plants. In this Forum paper, we ask whether the cost-benefit model applies equally well

34 to aquatic carnivorous plants and what general insights into trade-off models are gained by this

35 comparison. Nutrient limitation is more pronounced in terrestrial carnivorous plants, which also

36 have much lower growth rates and much higher ratio of dark respiration to photosynthetic rates

37 than aquatic carnivorous plants. Phylogenetic constraints on ecophysiological trade-offs among

38 carnivorous plants remain unexplored. Despite differences in detail, the general cost-benefit

39 framework continues to be of great utility in understanding the evolutionary ecology of

40 carnivorous plants. We provide a research agenda that if implemented would further our

41 understanding of ecophysiological trade-offs in carnivorous plants and also would provide 
42 broader insights into similarities and differences between aquatic and terrestrial plants of all 43 types.

44 


\section{Introduction}

46 Organisms cannot do everything equally well. Identification of trade-offs among physiological

47 and morphological traits (Shipley 2002; Shipley et al. 2006; He et al. 2009) and the use of such

48 traits in cost-benefit models and ecological or evolutionary optimization arguments (e.g.,

49 Givnish 1986; Raven et al. 2004; Ellison and Gotelli 2009) have been hallmarks of ecological

50 analysis for at least 50 years. Despite their obvious drawbacks and limitations (e.g., Gould and

51 Lewontin 1979; Lenormand et al. 2009; Nielsen 2009), cost-benefit models and their kin have

52 framed many ecological research programs and continue to provide new insights and

53 generalizations (Wright et al. 2004, 2005; Santiago and Wright 2007; Reich et al. 2007, 2009;

54 Ordoñez et al. 2009).

55 Givnish et al. (1984) provided one of the most significant applications of a cost-benefit

56 model to a long-standing problem in evolutionary ecology - an explanation for the repeated

57 evolution of botanical carnivory among at least six disparate plant lineages (Darwin 1875; Lloyd

58 1942; Benzing 1987; Juniper et al. 1989; Albert et al. 1992; Ellison and Gotelli 2001, 2009;

59 Chase et al. 2009). In short, Givnish et al. (1984) proposed that botanical carnivory - the

60 attraction, capture, and digestion or animal prey, and the subsequent direct uptake and use of

61 nutrients from that prey - would evolve when the marginal benefit derived from carnivory

62 (expressed as increased rates of photosynthesis or growth) exceeded the marginal cost

63 (expressed in units of carbon) required to construct animal traps. Because of its clarity and its

64 quantitative framework, the cost-benefit model for the evolution of botanical carnivory has been

65 the fundamental framework underlying carnivorous plant research since its publication in 1984

66 (see reviews in Adamec 1997a; Ellison 2006; Ellison and Gotelli 2009; and see Brewer et al.

672011 for an alternative approach). 
The cost-benefit model for the evolution of botanical carnivory was developed based on

69 data collected from a single carnivorous plant, the bromeliad Brocchinia reducta (Givnish et al.

70 1984), but it has been applied routinely to all carnivorous plants (Givnish et al. 1984; Benzing

71 1987; Ellison 2006). The majority of these $c a$. 650 species inhabit nutrient-poor habitats in

72 which light and water are rarely limiting (Benzing 1987, 2000; Brewer et al. 2011).

73 Approximately $90 \%$ of carnivorous plants can be considered "terrestrial"; they are firmly rooted

74 in sandy or peaty wetland soils (Juniper et al. 1989; Taylor 1989; Guisande et al. 2007), and

75 virtually all of the empirical studies applying the cost-benefit model for the evolution of

76 carnivory have examined terrestrial carnivorous plants (Ellison 2006). But the remaining 10\%

77 of carnivorous plants, including 50 species of bladderworts (Utricularia: Lentibulariceae) and

78 the water-wheel plant Aldrovanda vesiculosa (Droseraceae) are unrooted submerged or

79 amphibious aquatic plants (Taylor 1989; Adamec 1997b). Here, we ask whether the cost-benefit

80 model applies equally well to aquatic carnivorous plants and what general insights into trade-off

81 models are gained by this comparison.

82 In applying the cost-benefit model, why should it matter whether plants are aquatic or

83 terrestrial? First, the physical environments of aquatic and terrestrial habitats are quite different

84 (Sand-Jensen 1989; Barko et al. 1991; Sand-Jensen and Frost-Christensen 1998; Colmer and

85 Pedersen 2008). On land, $\mathrm{CO}_{2}$ is available as a gas at a relatively constant concentration and

86 diffuses rapidly into plant tissues through stomata (e.g., Lambers et al. 1998). In water, $\mathrm{CO}_{2}$ and

$87 \mathrm{O}_{2}$, the critical gases for photosynthesis and respiration, are dissolved in solution and diffusion

88 rates of dissolved solutes limit photosynthetic rate. Furthermore, uptake of $\mathrm{CO}_{2}$ by aquatic plants

89 is strongly dependent on $\mathrm{pH}$ and total alkalinity, and direct uptake of $\mathrm{CO}_{2}$ by aquatic plants

90 increases with concentrations of dissolved inorganic carbon, dissolved organic matter, and 
91 mineral nutrients in the aquatic environment. Although the shallow standing, oligo-mesotrophic

92 and dystrophic (organically-rich, humic) waters in which aquatic carnivorous plants grow may

93 have low concentrations of $\mathrm{O}_{2}$, these same waters usually (but not strictly) are very rich in free

$94 \mathrm{CO}_{2}$ (Adamec 1997a, 1997b, 2008a). These physical differences between aquatic and terrestrial

95 environments strongly suggest that key ecophysiological traits and processes (e.g.,

96 photosynthesis, growth rate, nutrient uptake) should differ between terrestrial and aquatic plants,

97 whether or not they are carnivorous (e.g., Sand-Jensen 1989; Lambers et al. 1998; Colmer and

98 Pedersen 2008).

99 Aquatic carnivorous plants are not common in all aquatic habitats. Shallow non-

100 dystrophic (clear) lakes usually host diverse communities of rooted and non-carnivorous aquatic

101 plants (Sand-Jensen 1989; Barko et al. 1991), whereas in dystrophic lakes and streams, species

102 diversity of rooted aquatic plants is relatively poor but the two genera of aquatic carnivorous

103 plants are abundant (e.g., Kamiński 1987a). Typical dystrophic waters are dark, have high

104 concentrations of humic acids and tannins, and loose, anoxic sediments (Kamiński 1987a, b,

105 Adamec 1997a, b); these conditions are not especially favorable for the growth and development

106 of rooted aquatic plants. In contrast, aquatic carnivorous plants float freely near the water's

107 surface where there is more light and free oxygen, but without roots to absorb nutrients, these

108 plants may have evolved carnivory to maximize nutrient capture. Similar selective pressures

109 may apply in terrestrial wetlands where terrestrial carnivorous plants are most common. In these

110 habitats, anoxic peats or excessively well-drained and leached sands creates strong nutrient

111 limitation and may have favored investment in alternative (i.e., carnivorous) structures for

112 capturing nutrients. 
Second, rooted plants take up nutrients through specialized structures - roots (and often

114 associated mycorrhizae) - and can store these nutrients in other specialized structures such as

115 rhizomes (when they are present).

116 In contrast, rootless aquatic plants obtain nutrients from the water column by diffusion

117 through unspecialized leaves and stems and specialized structures for long-term storage of

118 nutrients are rarely present. Although strictly speaking, the $\sim 170$ species of terrestrial

119 Utricularia lack roots, these species do have root-like underground shoots or stolons that, like

120 true roots, anchor the plants to the substrate and store nutrients (Taylor 1989). Thus, we consider

121 terrestrial Utricularia to be functionally "rooted" plants. In both terrestrial and aquatic habitats,

122 carnivorous plants also obtain nutrients from prey captured by specialized traps modified from

123 leaves (Arber 1941; Lloyd 1942; Adamec 1997a; Ellison and Gotelli 2009) and in terrestrial

124 habitats, prey capture has been shown to enhance nutrient uptake by roots (Aldenius et al. 1983;

125 Hanslin and Karlsson 1996; Adamec 2002). Analogous effects have not been found in aquatic

126 carnivorous plants (Adamec et al. 2010), nor have they been examined in terrestrial Utricularia.

127 In both terrestrial and aquatic habitats, an increase in availability of dissolved nutrients (in soil or

128 in the water column) is associated with a decrease in the production of carnivorous traps (Knight

129 and Frost 1991; Chiang et al. 2000; Guisande et al. 2000, 2004; Ellison and Gotelli 2002),

130 suggesting a clear energetic and/or mineral "cost" to their production. By examining and

131 synthesizing available data on growth and ecophysiological processes of carnivorous plants, we

132 assess whether or not there are differences in the associated marginal costs of nutrient uptake by

133 carnivorous plants growing in terrestrial and aquatic habitats.

134 Although most carnivorous plants are perennial, some are annual, and both life-histories

135 can be found among terrestrial and aquatic carnivorous plants. Among aquatic carnivorous 
136 plants, annual life-histories are uncommon in typical dystrophic habitats but are more common

137 in very shallow waters on sandy or clayish bottom in (sub)tropical regions where rapid growth

138 and reproduction may have been selected for in ephemeral habitats (Taylor 1989). Similarly,

139 among terrestrial carnivorous plants, annual life-histories are most frequent in sundews (Drosera

140 sp.) and rainbow plants (Byblis sp.) that occur in seasonally dry or episodically disturbed habitats

141 (Lowrie 1998).

142 Finally, aquatic plants are not found in all angiosperm clades, and aquatic carnivorous

143 plants are notable for their taxonomic restriction. All but one of the aquatic carnivorous plants

144 are in the single genus Utricularia (Lamiales: Lentibulariaceae), and are found only in a few

145 derived clades within that genus (Taylor 1989; Guisande et al. 2007). The one other aquatic

146 carnivorous plant is Aldrovanda vesiculosa, a derived carnivorous plant in the Droseraceae

147 (Caryophyllales). Thus, phylogenetic constraints may play a greater role in determining the

148 evolution of specific types or mechanisms of carnivory in (aquatic) Utricularia (Jobson et al.

149 2004) than in the more phylogenetically diverse terrestrial carnivorous plants.

150 In this paper, we first review our understanding of differences and similarities in

151 fundamental ecophysiological traits - structural characteristics, growth patterns and rates,

152 photosynthesis, and nutrient uptake and use - of aquatic and terrestrial carnivorous plants

153 (henceforth ACPs and TCPs, respectively). We then use these contrasts to assess cost-benefit

154 relationships among these traits in ACPs and TCPs and ask whether these patterns can inform

155 trait-based models for plants growing in either terrestrial or aquatic habitats. We then return to

156 the question of how phylogeny may have constrained observed patterns of the evolution of

157 botanical carnivory. Finally, we outline a set of research needs to further our understanding of

158 the evolutionary physiology of carnivorous plants and to incorporate them fully into general 
159 trait-based models of plant form and function (compare Wright et al. 2004, 2005; Reich et al.

160 2009; and Ordoñez et al. 2009 with Ellison 2006; and Karagatzides and Ellison 2009).

\section{Traits of aquatic and terrestrial carnivorous plants}

\section{Structural traits}

164 The growth forms of TCPs most commonly are sessile or erect rosettes, but there also are 165 carnivorous vines (Triphyophyllum) and erect-stemmed herbs (Drosophyllum, Roridula, Byblis)

166 (Juniper et al. 1989). Most TCPs possess true roots and many species also produce thick

167 rhizomes. Root-like rhizomes or stolons are produced even by otherwise rootless terrestrial 168 species of Utricularia and Genlisea (Juniper et al. 1989; Taylor 1989; Adamec 2005). The root 169 systems of TCPs are usually small, short, and poorly branched (the proportion of root dry mass 170 to the total plant dry mass ranges from 3 -23\%; Adamec 1997a). Nonetheless, roots, rhizomes, 171 and/or stolons anchor the plants, root uptake may contribute substantially to the nutrient budget 172 of TCPs (Adamec 1997a), and the physiological root activity per unit biomass is surprisingly

173 high (Adamec 2005). In contrast, ACPs are submerged or partially amphibious, rootless plants

174 that float freely in the water column or are weakly attached to loose sediments (Taylor 1989;

175 Guisande et al. 2007). Uptake of nutrients from the surrounding water supplements nutrients

176 obtained from captured prey (Lollar et al. 1971; Knight and Frost 1991; Friday and Quarmby

177 1994; Ulanowicz 1995; Guisande et al. 2000; Chiang et al. 2000; Adamec 2008a). Most ACPs

178 have a linear, modular shoot structure consisting of regularly produced and regularly shed nodes

179 with filamentous leaves and tubular, fragile internodes. In some species, the leaves are arranged

180 in true whorls. The linear shoots are either monomorphic (non-differentiated) or dimorphic,

181 differentiated into green photosynthetic shoots and pale carnivorous shoots with many traps 
182 (Taylor 1989; Guisande et al. 2007). Traps of both TCPs and ACPs are derived from modified

183 leaves (Arber 1941; Lloyd 1942; Juniper et al. 1989; see Ellison and Gotelli 2001 for a review

184 and illustrations). The traps of both terrestrial and aquatic Utricularia species are hollow

185 bladders, 2 cells thick and 1-6 mm in diameter (Juniper et al. 1989; Taylor 1989). The 4-6 mm

186 wide snap-traps of the aquatic Aldrovanda are similarly shaped, albeit much smaller, than those

187 of its terrestrial sister-group, the Venus' fly-trap, Dionaea muscipula (Juniper et al. 1989).

189 Growth

190 Aquatic and terrestrial carnivorous plants grow in different ways. Like most familiar plants,

191 TCPs produce new shoots and leaves while retaining, at least for a time, older shoots and leaves.

192 The result is a plant whose main axis and branches increase in size through time. In striking

193 contrast, ACPs have very rapid apical shoot growth but their basal shoot segments age and die at

194 about the same rate. For example, under favorable conditions, the apical shoot growth rate

195 ranges from $1.0-1.2$ whorls $\mathrm{d}^{-1}$ in Aldrovanda to as much as $2.8-4.2$ nodes/d in field or

196 culture-grown aquatic Utricularia species (Friday 1989; Adamec 2000, 2008c, 2009b, 2010a;

197 Adamec and Kovářová 2006), although relative growth rate ( $R G R$ in $\mathrm{g} \mathrm{g}^{-1} \mathrm{~d}^{-1}$ ) may appear to

198 approach zero (Adamec 2009b). The result of this "conveyer-belt" growth system is that ACPs

199 maintain a relatively constant length of the main shoot. Under normal conditions, however, shoot

200 branching accompanies main shoot extension, leading to RGRs of ACPs far exceeding zero.

201 The relative growth rate of both ACPs and TCPs is generally significantly lower than

202 most groups of non-carnivorous herbaceous plants $\left(\mathrm{F}_{5,423}=80.26, P<2 \times 10^{-16}\right.$, ANOVA; Fig.

203 1). Based on a broad review of published values (references in legend to Fig. 1), the RGRs of

204 ACPs and TCPs, along with rooted aquatic herbaceous plants (non-carnivorous) were low (of the 
205 order of $0.055 \mathrm{~g} \mathrm{~g}^{-1} \mathrm{~d}^{-1}$ for ACPs and $0.035 \mathrm{~g} \mathrm{~g}^{-1} \mathrm{~d}^{-1}$ for TCPs) and statistically indistinguishable

$206(P=0.83)$, but significantly lower than RGRs of terrestrial herbs $\left(P<1 \times 10^{-8}\right.$, post-hoc multiple

207 comparisons among means with Tukey's HSD test). We note that most of these data are from

208 seedlings or small plants, but in general these RGR values are not corrected for plant size and so

209 may confound relative growth rates and size (Rose et al. 2009; Rees et al. 2010). However,

210 relatively few data on RGR have been size-corrected, and previously published papers on RGR

211 generally do not provide sufficient information to apply the size-corrected models suggested by

212 Rose et al. (2009) or Rees et al. (2010). More definitive comparisons of RGR between

213 carnivorous and non-carnivorous plants, whether terrestrial or aquatic, will require reassessment

214 of relative growth rates in light of overall plant sizes at the time of measurement. In any case,

215 branching rate of the main shoot in ACPs is of crucial importance for both overall plant growth

216 and RGR (Kamiński 1987a; Adamec 2000, 2008c, 2009b, 2010a, 2011c).

218 Photosynthesis and dark respiration

219 In all TCPs, the traps are modified from leaves or leaf parts (Arber 1941; Lloyd 1942). In many

220 TCPs, the traps function simultaneously as nutrient capture organs and as photosynthetic organs,

221 although in the ca. 100 species of Nepenthes, the lamina (an expanded petiole) accounts for at

222 least $90 \%$ of photosynthesis and the traps (modified leaf blades) have negligible photosynthetic

223 rates (Pavlovič et al. 2007; Karagatzides and Ellison 2009). In ACPs, the situation is similar.

224 Aldrovanda traps both acquire nutrients and photosynthesize, but in Utricularia, traps are

225 specialized for prey capture and have much lower photosynthetic rates than the leaves.

226 Therefore, in comparing photosynthetic rates among groups, we use data from the primary

227 photosynthetic organs, but where possible, we also highlight differences between photosynthetic 
rates of leaves/lamina and traps. In discussing respiratory (maintenance) costs, we focus on the

229 ratio of dark respiration to photosynthesis.

230 Both TCPs and ACPs are C-3 plants (Lüttge 1983). However, maximum photosynthetic 231 rates vary dramatically between TCPs and ACPs $\left(\mathrm{F}_{5,259}=24.12, P<2 \times 10^{-16}\right.$, ANOVA; Fig. 2).

232 Mass-based maximum photosynthetic rates $\left(\mathrm{A}_{\mathrm{MAX}}\right)$ measured for TCPs range from 17-153 nmol

$233 \mathrm{CO}_{2} \mathrm{~g}^{-1}$ (dry mass) $\mathrm{s}^{-1}$, approximately 4-fold less than values commonly found for leaves non-

234 carnivorous herbs (Wright et al. 2004; Ellison and Farnsworth 2005; Ellison 2006; Fig. 2). In

235 contrast, $\mathrm{A}_{\mathrm{MAX}}$ of ACPs range from 73-517 $\mathrm{nmol} \mathrm{g}^{-1} \mathrm{~s}^{-1}$, whereas the usual values for submerged,

236 aquatic, non-carnivorous plants generally range from 75 to 240 (for rooted aquatic herbs) or 200

$237-450$ (for floating, unrooted aquatic herbs) $\mathrm{nmol} \mathrm{g}^{-1} \mathrm{~s}^{-1}$ (Fig. 2). That is, $\mathrm{A}_{\mathrm{MAX}}$ of ACPs is similar

238 to both unrooted aquatic non-carnivorous plants $(P=0.98)$ and rooted aquatic non-carnivorous

239 plants $(P=0.22)$, whereas $\mathrm{A}_{\mathrm{MAX}}$ of TCPs not only is significantly lower than that of terrestrial

240 non-carnivorous plants $P<1 \times 10^{-8}$ ), but it is also significantly lower than that of ACPs and

241 other aquatic plants $\left(P<1 \times 10^{-8}\right)$. The photosynthetic $\mathrm{CO}_{2}$ affinity (compensation

242 concentration) measured for ACPs averages $4.5 \mu \mathrm{M}$ and ranges from 0.7-13 $\mu \mathrm{M}$ (Adamec

243 1997b, 2009a; Adamec and Kovářová 2006; Pagano and Titus 2007), quite similar to that found

244 in non-carnivorous aquatic plants, which ranges from 1.5-10 $\mu \mathrm{M}$ (Maberly and Spence 1983).

245 We note that in general, $\mathrm{HCO}_{3}{ }^{-}$is of a very minor ecological importance in carbon budgets of

246 ACPs, although $\mathrm{HCO}_{3}{ }^{-}$may be used for photosynthesis by $U$. australis grown at very high $\mathrm{pH}$

247 (Adamec 2009b).

248 The large differences in photosynthetic rates between TCPs and ACPs only partly reflect

249 their minor differences in RGRs. An assessment of the relationship between respiration and

250 photosynthesis in ACPs and TCPs (Fig. 3), however, illuminates linkages between carbon 
251 fixation rates and RGR. Non-carnivorous herbaceous plants typically have dark respiration rates $252\left(\mathrm{R}_{\mathrm{D}}\right)<50 \%$ of $\mathrm{A}_{\text {MAX }}$ (Bazzaz and Carlson 1982). In contrast, the average $\mathrm{R}_{\mathrm{D}} / \mathrm{A}_{\mathrm{MAX}}$ ratio of TCPs 253 is much higher $(63 \%)$, whereas ACPs have a much lower ratio of $\mathrm{R}_{\mathrm{D}} / \mathrm{A}_{\mathrm{MAX}}$ (mean $=34 \%$, range $2544-190 \% ; \mathrm{F}_{1,40}=5.88, P=0.03$ ANOVA on $\ln$-transformed data). Interestingly, $\mathrm{R}_{\mathrm{D}}$ tends to 255 increase with $A_{\text {MAX }}$ for TCPs, but varies little for ACPs; $R_{D} / A_{\text {MAX }}$ is little affected by 256 supplemental feeding (Fig. 3). The much higher (absolute) values of $\mathrm{R}_{\mathrm{D}}$ in aquatic Utricularia 257 traps than in traps of TCPs support the observation of very energetically demanding 258 physiological function of water pumping that is unique to Utricularia (Jobson et al. 2004; 259 Adamec 2006).

The averages also mask significant differences between traps and leaves or

261 photosynthetic lamina in species where trapping and photosynthesis are accomplished by 262 different organs $\left(\mathrm{F}_{5,32}=18.84, P=0.002\right.$, nested ANOVA on $l n$-transformed data). In the TCPs 263 Nepenthes, Sarracenia, and Dionaea for which those $\mathrm{A}_{\mathrm{MAX}}$ and $\mathrm{R}_{\mathrm{D}}$ have been measured 264 separately on traps (pitchers and snap-traps, respectively) and laminae (lamina, phyllodia, and 265 petioles, respectively), the traps have much higher respiratory costs (mean $R_{D} / A_{M A X}=158 \%$, 266 range $=13-325 \%)$ than do the laminae (mean $=19 \%$, range $=9-33 \%)($ Fig. 3). For TCPs such 267 as Drosera, Pinguicula and Sarracenia in which traps are modified leaves and both $\mathrm{R}_{\mathrm{D}}$ and $\mathrm{A}_{\mathrm{MAX}}$ 268 were measured on these modified leaves, $\mathrm{R}_{\mathrm{D}} / \mathrm{A}_{\mathrm{MAX}}$ averages $68 \%$ (range $10-149 \%$ ). Similarly, 269 respiratory costs of very weakly photosynthezing traps of the aquatic Utricularia (mean $R_{D} / A_{M A X}$ $270=106 \%$, range $32-190 \%$ ) are much higher than its leaves (mean $=9 \%$, range $4-90 \%$ ). Even 271 when traps and leaves of Utricularia are assayed together, their $\mathrm{R}_{\mathrm{D}} / \mathrm{A}_{\mathrm{MAX}}$ ratio is much lower 272 than that of TCPs $($ mean $=21 \%$, range $9-38 \%)($ Fig. 3). 
The substantial differences in the relative respiratory costs between ACPs and TCPs are

274 related to their distinct methods of growth. We conclude that low $A_{M A X}$ values and high $R_{D} / A_{M A X}$

275 ratios of TCPs are a typical, convergent, attribute of this group of plants and reflect

276 physiological consequences of slow growth, and storage of C over often long lifespans (Butler

277 and Ellison 2007). On the other hand, the very low $R_{D} / A_{M A X}$ of ACPs reflects their rapid growth

278 and turnover of senescent shoots that leads to large and predictable losses of structural and non-

279 structural carbohydrates (Adamec 2000). Unlike TCPs that store C for future use, a substantial

280 amount ( 20-25\%) of the total photosynthetically fixed C is secreted by aquatic Utricularia

281 traps into trap fluid where it supports the commensal assemblage within the trap (Sirová et al.

282 2010).

283

284 Nutrient uptake and use

285 It has been demonstrated repeatedly that the primary benefit of trapping and consuming insect

286 prey is to obtain growth-limiting mineral nutrients, mainly $\mathrm{N}$ and $\mathrm{P}$ (see reviews in Juniper et al.

287 1989; Adamec 1997a, 2002; Ellison 2006). How this benefit is expressed, however, differs

288 among some carnivorous plant taxa and is unknown for others. For example, in several pitcher

289 plants (Sarracenia and Nepenthes), $\mathrm{A}_{\mathrm{MAX}}$ increases with foliar N or P (Ellison and Farnsworth

290 2005; Pavlovič et al. 2007; Farnsworth and Ellison 2008). In Drosera and Pinguicula, capture of

291 prey by traps stimulates additional uptake of mineral nutrients from the soil (Hanslin and

292 Karlsson 1996; Adamec 1997a, 2002). Root uptake can further enhance $A_{\text {MAX }}$ (Pavlovič et al.

293 2010). Downstream, the consequence of prey addition usually results in increased growth

294 expressed as more leaves, branches, and/or biomass (Ellison 2006). These data lead us to

295 hypothesize that $\mathrm{N}$ and $\mathrm{P}$ derived from prey enhance essential growth processes in ACPs such as 
296 cell division, DNA replication, and protein synthesis in the young, meristematic tissues of shoot

297 apices (Adamec 2008b). This hypothesis is supported only for Aldrovanda but not for two

298 Utricularia species (Adamec 2011a). Together with observations that TCPs shunt excess $\mathrm{N}$ to

299 new growth (Butler and Ellison 2007), these data all suggest that the effects of enhanced prey

300 capture are manifest on young, developing tissues and organs rather than on mature, existing

301 organs (Ellison and Gotelli 2002, 2009).

302

TCPs have significantly lower foliar N, P, and K than all other functional groups of

303 terrestrial non-carnivorous plants (Ellison 2006). In contrast, macronutrient content in shoots of

304 ACPs is $\sim 2-5$ times greater than that of TCPs (Fig. 4) and comparable to that of aquatic non-

305 carnivorous plants (Dykyjová 1979). Phosphorus content is much more variable among ACPs

306 than among TCPs - up to 10- to 20-fold within the same species - but it could be overestimated

307 in ACPs with their closed traps if remnants of captured prey are inadvertently analyzed (Adamec

308 2008a). Like TCPs, K content in ACPs is substantially greater than N content, and P content of

309 ACPs is nearly double that of terrestrial forbs, which otherwise have the highest foliar nutrient

310 content among the different functional groups examined by Wright et al. (2005). Also unlike

311 TCPs, average tissue macronutrient contents of ACPs are well above the "critical levels" (blue

312 lines in Fig. 4) that limit growth in both aquatic and terrestrial plants (Gerloff and Krombholz

313 1966; Ellison 2006). Stoichiometrically, ACPs show no consistent patterns with respect to

314 nutrient limitation, whereas TCPs tend to be primarily $\mathrm{P}$ or $\mathrm{P}+\mathrm{N}$ limited (Fig. 5).

315 Variation in nutrient content within individual ACPs reflects the steep nutrient polarity

316 along shoots, localization of traps along the shoot, and also captured prey (Adamec 1997a, 2000,

317 2008a). Thus, the growth rates of ACPs (Fig. 1) are associated with high $\mathrm{A}_{\text {MAx }}$ (Fig. 2),

318 relatively low $\mathrm{R}_{\mathrm{D}}$ (Fig. 3), and high shoot nutrient contents (Fig. 4). Nevertheless, very rapid 
319 growth of ACPs that were experimentally fed additional prey in situations led to significant

320 decrease in tissue $\mathrm{N}$ and P content in apical shoot segments (Adamec 2000; 2008a, 2011a).

321 Similar results also have been observed in non-carnivorous aquatic plants (e.g., Titus and

322 Andorfer 1996) and in adult shoots of several TCPs (Adamec 1997a, 2002). This observation

323 may be partly the result of an apparent "dilution" of mineral nutrients by organic substances in

324 plant tissues of rapidly growing plants.

325 Potassium (K) has been much less studied in carnivorous plants (Adamec 1997a; Ellison

326 2006), but tissue $\mathrm{K}$ content in traps of aquatic Utricularia species (3.7-8.7 \% of dry mass) is

327 much higher than in its leaves or shoots (Adamec 2008a, 2010b), probably reflecting particular

328 trap functions. The highest concentrations of $\mathrm{K}$ found in Utricularia traps exceed any reported

329 for non-carnivorous aquatic plants (cf. Dykyjová 1979). However, it is not known whether this

330 high $\mathrm{K}$ content is restricted to trap walls or the specialized quadrifid glands within the trap.

331 The effect of supplemental prey on growth of both TCPs and ACPs is generally positive

332 (Adamec 1997a; Ellison 2006), but weak in aquatic Utricularia species, in which the effect

333 depends markedly on $\mathrm{pH}$ and $\mathrm{CO}_{2}$ availability (Kosiba 1992a; Adamec 2008a; Adamec et al.

334 2010). However, both ACPs and TCPs efficiently take up nutrients from prey carcasses. Thirty

335 to $76 \%$ of prey-N is taken up by TCPs (Hanslin and Karlsson 1996; Adamec 1997a, 2002; Butler

336 and Ellison 2007; Butler et al. 2008) and over $80 \%$ is taken up by the aquatic $U$. vulgaris (Friday

337 and Quarmby 1994). Similarly, TCPs take up $57-96 \%$ of P, K, Mg, and micronutrients from

338 prey (Plummer and Kethley 1964; Adamec 2002; Adlassnig et al. 2009). Although comparable

339 quantitative data are lacking for ACPs, we hypothesize that uptake of P, K, and Mg in ACPs

340 should also be very efficient. 
Finally, a number of TCPs efficiently re-use N, P, and K from senescent leaves, and this

342 re-use is much greater than that found in terrestrial non-carnivorous plants that co-occur with

343 TCPs in bogs or fens (Adamec 1997a, 2002; Butler and Ellison 2007). In contrast, in the aquatic

344 Aldrovanda and U. australis, only $\mathrm{N}$ and $\mathrm{P}$, not $\mathrm{K}$, has been found to be re-utilized from old

345 shoots (Adamec 2000, 2008a). It appears that rapidly growing ACPs lose all stored K with their

346 old shoots and have to acquire all K needed for new growth from prey or from the ambient

347 water. When it has been studied, reutilization rates of $\mathrm{Mg}$ and $\mathrm{Ca}$ by both ACPs and TCPs have

348 been found to be very low or even zero (Adamec 1997a, 2000, 2002, 2008a).

\section{Cost-benefit relationships in aquatic and terrestrial carnivorous plants}

352 The cost-benefit model for the evolution of carnivory by plants posits that (a) carbon costs of 353 carnivorous structures increase linearly (or at least monotonically), (b) that benefits of prey 354 capture are manifest in increased photosynthesis (or growth), but that these benefits increase 355 only up to a point and then reach an asymptote, and (c) that carnivory is favored when the 356 marginal benefits exceed the marginal costs (Givnish et al. 1984). Our review of

357 ecophysiological characteristics, structural traits, and patterns of growth illustrate that cost358 benefit trade-offs are likely to differ between ACPs and TCPs in some ways but are similar in 359 others. In summarizing the costs and benefits, we note that very few studies have simultaneously 360 measured both costs and benefits for any carnivorous plant (Méndez and Karlsson 1999; Ellison 361 and Farnsworth 2005; Adamec 2008c, 2011a; Farnsworth and Ellison 2008; Karagatzides and 362 Ellison 2009). Such studies are clearly an important area for future research. 
364 limited by nutrient availability than are ACPs (Fig. 4), and this difference is expressed in the 365 somewhat higher RGR (Fig. 1) and much higher $\mathrm{A}_{\mathrm{MAX}}$ (Fig. 2) of ACPs relative to TCPs.

366 Stoichiometrically, ACPs appear to be K- or P-limited whereas TCPs tend to be N-limited (Fig.

367 5). The cost-benefit model for the evolution of botanical carnivory emphasized $\mathrm{N}$ limitation, as

$368 \mathrm{~N}$ often limits $\mathrm{A}_{\mathrm{MAX}}$. Because traps of ACPs are energetically very costly, it is plausible that $\mathrm{P}$

369 limitation (of, e.g., ATP) might be of more consequence for ACPs than for TCPs. Evolutionary

370 innovations within respiratory pathways of Utricularia also appear to reflect the selective

371 pressures attendant to these costs (Jobson et al. 2004). Similarly, cellular signalling within the

372 rapidly responsive traps of both Aldrovanda and Utricularia may be limited by K availability

373 (Adamec 2010b); it would be of interest to determine if similar limitation is observed in Dionaea

374 (the sister group of Aldrovanda). In support of this hypothesis, mineral costs of carnivory -

375 especially of $\mathrm{K}$ and $\mathrm{P}$ - exceed $50 \%$ of total plant $\mathrm{K}$ and $\mathrm{P}$ amount in several ACP species

376 (Adamec 2010b); we hypothesize that the proportion will be lower in most TCP species with 377 separate traps.

378 Both ACPs and TCPs have relatively high respiration rates, but $\mathrm{R}_{\mathrm{D}}$ increases much more 379 rapidly with $\mathrm{A}_{\mathrm{MAX}}$ in TCPs than it does in ACPs (Fig. 3). At least for Utricularia, this may reflect 380 the aforementioned mutation in the cytochrome $c$ oxidase pathway (Jobson et al. 2004), but the 381 parallel high $\mathrm{A}_{\mathrm{MAX}}$ relative to $\mathrm{R}_{\mathrm{D}}$ observed in Aldrovanda cannot be explained in the same way. 382 However, Aldrovanda and Utricularia, like terrestrial carnivorous plants in the genera Dionaea, 383 Nepenthes, Cephalotus, Genlisea, have traps that are distinctly separate from photosynthetic 384 laminae. Although most studies of ACPs measure photosynthesis and respiration separately in 385 leaves and traps, only recently have comparable studies of TCPs distinguished between traps and 

lamina (Pavlovič et al. 2007; Hájek and Adamec 2009; Karagatzides and Ellison 2009). The

387 relationship between $A_{M A X}$ and $R_{D}$ in all carnivorous plants may become clearer as these

388 characteristics are measured separately on traps and leaves or laminae of a larger number of 389 species.

390 Despite the differences in detail, however, the general cost-benefit framework continues

391 to be of great utility in understanding the evolutionary ecology of carnivorous plants. Both ACPs 392 and TCPs are limited by available resources and must allocate nutrients and carbon to base 393 metabolic functions, current and future growth (storage), and development of organs - traps 394 and/or roots - to provide additional opportunities for obtaining and taking up nutrients.

\section{Conclusions and challenges for further research}

398 Carnivorous plants have been model systems for studying a wide range of ecophysiological and 399 ecological processes (Adamec 1997a; Ellison and Gotelli 2001; Ellison et al. 2003) and have 400 provided novel insights into trait-based models of ecological and evolutionary trade-offs. Central 401 to the cost-benefit model for the evolution of botanical carnivory is the relationship between 402 nutrients and photosynthesis. How do carnivorous plants efficiently obtain scarce nutrients that 403 are supplied primarily in organic form as prey, digest and mineralize them so that they can be 404 readily used, and allocate them to immediate needs (e.g., increase photosynthetic activity to 405 provide energy for "expensive" traps) as opposed to future needs (e.g., storage for subsequent 406 years' growth or flowering)? Beginning with Darwin (1875), studies of carnivorous plants have 407 elaborated the diversity of mechanisms used by carnivorous plants to capture and digest prey 408 (e.g., reviews in Juniper et al. 1989, Ellison and Gotelli 2009). 
410 nutrient uptake on the one hand and photosynthesis on the other. The majority of pitcher

411 plants (Darlingtonia californica, Sarracenia spp., Nepenthes sp.) show correlated increases in

412 foliar $\mathrm{N}$ and $\mathrm{P}$ content, growth rate, and $\mathrm{A}_{\mathrm{MAX}}$ following prey addition (Ellison and Farnsworth

413 2005; Wakefield et al. 2005; Farnsworth and Ellison 2008; Pavlovič et al. 2009). Comparable

414 data for aquatic carnivorous plants are rare and inconsistent (Adamec 2000, 2008c, 2011a;

415 Adamec et al. 2010). In part, this contrast reflects the relative ease of studying prey

416 mineralization and nutrient uptake in terrestrial pitcher plants with their large pitchers (e.g.,

417 Butler and Ellison 2007; Butler et al. 2008; Karagatzides et al. 2009) and the difficulty of

418 studying similar phenomena in aquatic Utricularia with their tiny bladders (e.g., Englund and

419 Harms 2003; Adamec 2008a, 2008c).

420 Studies on TCPs have focused primarily on N, and to a lesser extent, P, which have been

421 shown repeatedly to be limiting nutrients for these plants (Figs. 4, 5). Aquatic carnivorous

422 plants, on the other hand, show much more variability both in tissue nutrient content (Fig. 4) and

423 stoichiometric nutrient limitation (Fig. 5). A few studies have suggested that uptake of P, K, and

$424 \mathrm{Mg}$ from prey could enhance photosynthesis of ACPs (Adamec 2008c) and that these nutrients

425 may be as important to ACPs as N is to TCPs (Friday and Quarmby 1994; Adamec et al. 2010).

426 However, methodological barriers must be overcome before direct measurements of linkages

427 between these nutrients and $\mathrm{A}_{\mathrm{MAX}}$ can be made in ACPs. Similar barriers have limited studies of

428 the efficiency of mineral nutrient uptake from prey carcasses in ACPs (Friday and Quarmby

429 1994; Adamec et al. 2010).

431 uptake from prey capture by carnivorous plants? We have previously suggested that prey- 
432 derived $\mathrm{N}$ and $\mathrm{P}$ increase cell division, DNA replication, and protein synthesis in young

433 meristematic tissues of shoot apices of ACPs account for the very rapid growth of their apical

434 shoots (Adamec 2008c). Because effects of prey addition are manifest primarily on young,

435 developing tissues and organs rather than in mature, existing organs (Ellison and Gotelli 2002,

436 2009), such effects may not be apparent in short-term experiments. Because of the large

437 differences in shoot morphology and growth dynamics of ACPs and TCPs (e.g. Fig. 1) there is

438 unlikely to be a single mechanism by which carnivory stimulates growth in both groups.

440 by roots of TCPs is stimulated following prey capture (Hanslin and Karlsson 1996; Adamec

441 1997a, 2002). Aquatic carnivorous plants lack roots; might prey addition stimulate mineral

442 nutrient uptake by shoots from the ambient water? Adamec et al. (2010) found that shoot $\mathrm{N}$ and

443 P uptake by A. vesiculosa increases following prey capture, but a similar effect was not observed

444 for $U$. australis. What is the mechanism for these effects in TCPs and Aldrovanda? Does

445 nutrient uptake affinity or capacity increase with prey capture or tissue nutrient content, leading

446 to a positive feedback loop that ultimately increases uptake rate? Detailed examination of

447 physiological and hormonally regulated processes - photosynthetic rates, transport of

448 photosynthates to roots, tissue mineral nutrient content in both shoots and roots, root anatomy,

449 mineral nutrient uptake by excised roots, and phytohormone content in roots - should be taken

450 into account.

451 Furthermore, as animal prey is a poor source of $\mathrm{K}$, and because $\left[\mathrm{K}^{+}\right]$in the ambient water 452 can be very low and growth limiting (Adamec 1997a), we hypothesize that $\mathbf{K}^{+}$uptake affinity 453 of ACPs is extremely high. A focus on studying K uptake characteristics in shoots of ACPs is 454 warranted by the fact that, unlike TCPs, ACPs reutilize virtually no K from senescent shoots 
455 although the shoot content of K in ACPs is very high (Fig. 4). We also were unable to find any

456 studies on K reutilization from senescent shoots in non-carnivorous plants, and so comparative

457 studies of $\mathrm{K}$ dynamics in any aquatic plant would be welcome. Finally, we suggest that the

458 nature of the stimulation of root nutrient uptake by the foliar nutrient uptake should be studied in

459 model species of TCPs as well, with particular attention to Drosera and Dionaea, the terrestrial

460 sister taxa of Aldrovanda.

461 The nutritional benefit of carnivory, defined as the ratio between the gain (direct and

462 indirect) of certain mineral nutrients from carnivory and the loss of those nutrients in

463 construction of traps, has recently been introduced by Adamec (2011b) to supplement the classic

464 cost-benefit model (Givnish et al. 1984). To be nutritionally beneficial, carnivorous plants must

465 not only capture prey efficiently but also maximize nutrient uptake from prey and minimize

466 nutrient losses in senescent traps. Therefore, it is expected that the nutritional cost-benefit ratio

467 was of principal importance during the evolution of different carnivorous plant taxa, both

468 terrestrial and aquatic. New data on nutritional benefit in TCPs show relatively high cost-benefit

469 ratios for $\mathrm{N}$ and $\mathrm{P}$ but smaller ones for $\mathrm{K}$ and $\mathrm{Mg}$ (Adamec 2011b). Future research will reveal if

470 there any differences in nutritional benefits of carnivory between TCPs and ACPs.

471 Finally, what is the phylogenetic signal in linkages between prey capture, nutrient

472 dynamics, growth, and photosynthesis in carnivorous plants? Although robust species-level

473 phylogenies of most carnivorous plant groups are now available (reviewed by Ellison and

474 Gotelli 2009), experimental work, especially on ACPs, is taxonomically restricted. Jobson et al.

475 (2004) found a unique mutation in the cytochrome $c$ oxidase pathway in Utricularia that helps to

476 deal with the high energetic cost of its unique trap. Aquatic Utricularia are all derived from

477 terrestrial ancestors, and both the loss of true roots (but not root-like structures) preceded 
478 colonization of, and adaptation to, aquatic habitats. The cytochrome $c$ oxidase mutation is not 479 restricted to aquatic Utricularia but it is possible that there are other synapomorphies that are 480 present only in aquatic members of this genus. For example, does the apparent absence of a 481 feedback between prey addition and shoot uptake of dissolved nutrients by Utricularia reflect 482 phylogenetic constraints in the aquatic clades of this genus? In light of the recent finding of food 483 web operation inside traps of aquatic Utricularia (Sirová et al. 2009), the proposed nutritional 484 benefit for the plants from these mutualistic interactions - uptake of $\mathrm{N}$ and $\mathrm{P}$ from phytoplankton 485 and detritus - deserves focused attention. 


\section{Acknowledgements}

489 AME's work on carnivorous plant has been supported by grants from the US National Science 490 Foundation: 98-05722, 02-35238, 03-01361, 03-30605, and 05-41680. LA's work on this study

491 was supported by the Research Programme of the Academy of Sciences of the Czech Republic, 492 No. AV0Z60050516. Three anonymous reviewers provided constructive comments on the 493 manuscript.

494 


\section{References}

496 Adamec, L. 1997a. Mineral nutrition of carnivorous plants: a review. - Bot. Rev. 63: 273-299.

497 Adamec, L. 1997b. Photosynthetic characteristics of the aquatic carnivorous plant Aldrovanda

498 vesiculosa. - Aquat. Bot. 59: 297-306.

499 Adamec, L. 1999. Seasonal growth dynamics and overwintering of the aquatic carnivorous plant

$500 \quad$ Aldrovanda vesiculosa at experimental field sites. - Folia Geobot. 34: 287-297.

501 Adamec, L. 2000. Rootless aquatic plant Aldrovanda vesiculosa: physiological polarity, mineral

502 nutrition, and importance of carnivory. - Biol. Plant. 43: 113-119.

503 Adamec, L. 2002. Leaf absorption of mineral nutrients in carnivorous plants stimulates root

504 nutrient uptake. - New Phytol. 155: 89-100.

505 Adamec, L. 2005. Ecophysiological characterization of carnivorous plant roots: oxygen fluxes, respiration, and water exudation. - Biol. Plant. 49: 247-255.

507 Adamec, L. 2006. Respiration and photosynthesis of bladders and leaves of aquatic Utricularia

$508 \quad$ species. - Plant Biol. 8: 765-769.

509 Adamec, L. 2008a. Mineral nutrient relations in the aquatic carnivorous plant Utricularia

$510 \quad$ australis and its investment in carnivory. - Fund. Appl. Limnol. 171: 175-183.

511 Adamec, L. 2008b. Soil fertilization enhances growth of the carnivorous plant Genlisea violacea.

$512-$ Biologia 63: 201-203.

513 Adamec, L. 2008c. The influence of prey capture on photosynthetic rate in two aquatic

$514 \quad$ carnivorous plant species. - Aquat. Bot. 89: 66-70.

515 Adamec, L. 2009a. Ecophysiological investigation on Drosophyllum lusitanicum: why doesn't 516 the plant dry out? - Carniv. Plant Newslett. 38: 71-74. 
517 Adamec, L. 2009b. Photosynthetic $\mathrm{CO}_{2}$ affinity of the aquatic carnivorous plant Utricularia 518 australis (Lentibulariaceae) and its investment in carnivory. - Ecol. Res. 24: 327-333.

519 Adamec, L. 2010a. Field growth analysis of Utricularia stygia and U. intermedia - two aquatic 520 carnivorous plants with dimorphic shoots. - Phyton 49: 241-251.

521 Adamec, L. 2010b. Mineral cost of carnivory in aquatic carnivorous plants. - Flora 205: 618621.

523 Adamec, L. 2011a. By which mechanism does prey capture enhance plant growth in aquatic carnivorous plants: Stimulation of shoot apex? - Fund. Appl. Limnol. 178: 171-176.

525 Adamec, L. 2011b. Ecophysiological look at plant carnivory: Why are plants carnivorous? - In: Seckbach J., Dubinski Z. (eds.), All Flesh is Grass. Springer, pp. 455-489.

527 Adamec, L. 2011c. Shoot branching of the aquatic carnivorous plant Utricularia australis as the 528 key process of plant growth. - Phyton (in press).

Adamec, L. and Kovářová, M. 2006. Field growth characteristics of two aquatic carnivorous plants, Aldrovanda vesiculosa and Utricularia australis. - Folia Geobot. 41: 395-406.

531 Adamec, L. and Lev, J. 1999. The introduction of the aquatic plant Aldrovanda vesiculosa to new potential sites in the Czech Republic: a five-year investigation. - Folia Geobot. 34:

534 Adamec, L., Sirová, D. and Vrba, J. 2010. Contrasting growth effects of prey capture in two aquatic carnivorous plant species. - Fund. Appl. Limnol. 176: 153-160.

536 Adlassnig, W., Steinhauser, G., Peroutka, M., Musilek, A., Sterba, J. H., Lichtscheidl, I. K. and Bichler, M. 2009. Expanding the menu for carnivorous plants: uptake of potassium, iron and manganese by carnivorous pitcher plants. - Appl. Radiat. Isot. 67: 2117-2122. 
Albert, V. A., Williams, S. E. and Chase, M. W. 1992. Carnivorous plants: phylogeny and structural evolution. - Science 257: 1491-1495.

Aldenius, J., Carlsson, B. and Karlsson, S. 1983. Effects of insect trapping on growth and nutrient content of Pinguicula vulgaris L. in relation to the nutrient content of the substrate. - New Phytol. 93: 53-59.

Arber, A. 1941. On the morphology of the pitcher-leaves in Heliamphora, Sarracenia,

Barko, J. W., Gunnison, D. and Carpenter, S. R. 1991. Sediment interactions with submersed macrophyte growth and community dynamics. - Aquat. Bot. 41: 41-65.

Bazzaz, F. A. and Carlson, R. W. 1982. Photosynthetic acclimation to variability in the light environment of early and late successional plants. - Oecologia 54: 313-316.

Benzing, D. H. 1987. The origin and rarity of botanical carnivory. - Trends Ecol. Evol. 2: 364369.

Benzing, D. H. 2000. Bromeliaceae: profile of an adaptive radiation. - Cambridge Univ. Press.

Bern, A. L. 1997. Studies on nitrogen and phophorus uptake by the carnivorous bladderwort Utricularia foliosa L. in south Florida wetlands. - M.Sc. thesis, Florida International University, Miami, Florida, USA.

Boston, H. L., Adams, M. S. and Madsen, J. D. 1989. Photosynthetic strategies and productivity in aquatic systems. - Aquat. Bot. 34: 27-57. 
Bruzzese, B. M., Bowler, R., Massicotte, H. B. and Fredeen, A. L. 2010. Photosynthetic light response in three carnivorous plant species: Drosera rotundifolia, D. capensis, and Sarracenia leucophylla. - Photosynthetica 48: 103-109.

Butler, J. L. and Ellison, A. M. 2007. Nitrogen cycling dynamics in the carnivorous pitcher plant, Sarracenia purpurea. - Funct. Ecol. 21: 835-843.

Butler, J. L., Gotelli, N. J. and Ellison, A. M. 2008. Linking the brown and green: nutrient transformation and fate in the Sarracenia microecosystem. - Ecology 89: 898-904.

Chase, M. W., Christenhusz, M. J. M., Sanders, D. and Fay, M. F. 2009. Murderous plants:

568
Victorian gothic, Darwin, and modern insights into vegetable carnivory. - Bot. J. Linn. Soc. 161: 329-356.

Chiang, C., Craft, C. B., Rogers, D. W. and Richardson, C. J. 2000. Effects of 4 years of nitrogen and phosphorus additions on Everglades plant communities. - Aquat. Bot. 68: 61-78.

575 Darwin, C. 1875. Insectivorous plants. - Appleton and Co.

Dykyjová, D. 1979. Selective uptake of mineral ions and their concentration factors in aquatic higher plants. - Folia Geobot. Phytotax. 14: 267-325.

Englund, G. and Harms, S. 2003. Effects of light and microcrustacean prey on growth and investment in carnivory in Utricularia vulgaris. - Freshwater Biol. 48: 786-794.

Eissenstat, D. M. and Caldwell, M. M. 1987. Characteristics of successful competitors: an evaluation of potential growth rate in two cold desert tussocks. - Oecologia 71: 167-173. 
Ellison, A. M. 2006. Nutrient limitation and stoichiometry of carnivorous plants. - Plant Biol. 8: 740-747.

Ellison, A. M. and Farnsworth, E. J. 2005. The cost of carnivory for Darlingtonia californica (Sarraceniaceae): evidence from relationships among leaf traits. - Am. J. Bot. 92: 10851093.

Ellison, A. M. and Gotelli, N. J. 2001. Evolutionary ecology of carnivorous plants. - Trends Ecol. Evol. 16: 623-629.

Ellison, A. M. and Gotelli, N. J. 2002. Nitrogen availability alters the expression of carnivory in the northern pitcher plant Sarracenia purpurea. - Proc. Nat. Acad. Sci., USA 99: 4409-

Ellison, A. M. and Gotelli, N. J. 2009. Energetics and the evolution of carnivorous plants Darwin's "most wonderful plants in the world". - J. Exp. Bot. 60: 19-42.

Ellison, A. M., Gotelli, N. J., Brewer, J. S., Cochran-Stafira, L., Kneitel, J., Miller, T. E., 4412. Worley, A. S. and Zamora, R.. 2003. The evolutionary ecology of carnivorous plants. Adv. Ecol. Res. 33: 1-74.

Farnsworth, E. J. and Ellison, A. M. 2008. Prey availability directly affects physiology, growth, nutrient allocation and scaling relationships among leaf traits in 10 carnivorous plant species. - J. Ecol.. 96: 213-221.

Fenner, M. 1983. Relationships between seed weight, ash content and seedling growth in twentyfour species of Compositae. - New Phytol. 95: 697-706.

Friday, L. and Quarmby, C. 1994. Uptake and translocation of prey-derived ${ }^{15} \mathrm{~N}$ and ${ }^{32} \mathrm{P}$ in Utricularia vulgaris L. - New Phytol. 126: 273-281.

Friday, L. E. 1989. Rapid turnover of traps in Utricularia vulgaris L. - Oecologia 80: 272-277. 
605 Gerloff, G. C. and Krombholz, P. H. 1966. Tissue analysis as a measure of nutrient availability

606 for the growth of angiosperm aquatic plants. - Limnol. Oceanogr. 11: 529-537.

607 Givnish, T. J. 1986. On the economy of plant form and function. - Cambridge Univ. Press.

608 Givnish, T. J., Burkhardt, E. L., Happel, R. E. and Weintraub, J. D. 1984. Carnivory in the bromeliad Brocchinia reducta, with a cost/ benefit model for the general restriction of carnivorous plants to sunny, moist nutrient-poor habitats. - Am. Nat. 124: 479-497.

611 Gould, S. J. and Lewontin, R. C. 1979. The spandrels of San Marco and the Panglossian paradigm: a critique of the adaptationist programme. - Proc. R. Soc., London B205: 581598.

Grime, J. P. and Hunt, R. 1975. Relative growth-rate: its range and adaptive significance in a local flora. - J. Ecol. 63: 393-422.
Guisande, C., Andrade, C., Granado-Lorencio, C., Duque, S. R. and Núñez-Avellaneda, M. 2000. Effects of zooplankton and conductivity on tropical Utricularia foliosa investment in carnivory. - Aquat. Ecol. 34: 137-142.

Guisande, C., Aranguren, N., Andrade-Sossa, C., Prat, N., Granado-Lorencio, C., Barrios, M. L.,

Guisande, C., Granado-Lorencio, C., Andrade-Sossa, C. and Duque, S. R. 2007. Bladderworts. Bolivar, A., Núñez-Avellaneda, M. and Duque, S. R. 2004. Relative balance of the cost Funct. Plant Sci. Biotech. 1: 58-68. carnivorous plants. - Biologia 65: 69-74. 
627 Hanslin, H. M. and Karlsson, P. S. 1996. Nitrogen uptake from prey and substrate as affected by prey capture level and plant reproductive status in four carnivorous plant species. Oecologia 106: 370-375.

He, J.-S., Want, X., Flynn, D. F. B., Wang, L., Schmid, B. and Fang, J. 2009. Taxonomic, phylogenetic, and environmental trade-offs between leaf productivity and persistence. -

633 Hunt, R. and Cornelissen, J. H. C. 1997. Components of relative growth rate and their

Jobson, R. W., Nielsen, R., Laakkonen, L., Wilkström, M. and Albert, V. A. 2004. Adaptive evolution of cytochrome $c$ oxidase: infrastructure for a carnivorous plant radiation. Proc. Nat. Acad. Sci., USA 101: 18064-18068.

Juniper, B. E., Robins, R. J. and Joel, D. M. 1989. The carnivorous plants. - Academic Press.

Kahara, S. N. and Vermaat, J. E. 2003. The effect of alkalinity on photosynthesis-light curves and inorganic carbon extraction capacity of freshwater macrophytes. - Aquat. Bot. 75:

642 Kamiński, R. 1987a. Studies on the ecology of Aldrovanda vesiculosa L. I. Ecological differentiation of $A$ vesiculosa population under the influence of chemical factors in the habitat. - Ekol. Pol. 35: 559-590.

Kamiński, R. 1987b. Studies on the ecology of Aldrovanda vesiculosa L. II. Organic substances, physical and biotic factors and the growth and development of A. vesiculosa. - Ekol. Pol. 35: 591-609. 
Karagatzides, J. D., Butler, J. L. and Ellison, A. M. 2009. The pitcher plant Sarracenia purpurea can directly acquire organic nitrogen and short-circuit the nitrogen cycle. - PLoS ONE 4: e6164.

Karagatzides, J. D. and Ellison, A. M. 2009. Construction costs, payback times, and the leaf economics of carnivorous plants. - Am. J. Bot. 96: 1612-1619.

Keddy, P., Fraser, L. H. and Wisheu, I. C. 1998. A comparative approach to examine competitive response of 48 wetland plant species. - J. Veg. Sci. 9: 777-786.

Klavsen, S. K. and Maberly, S. C. 2010. Effect of light and $\mathrm{CO}_{2}$ on inorganic carbon uptake in the invasive aquatic CAM-plant Crassula helmsii. - Funct. Plant Biol. 37: 737-747.

Knight, S. E. 1992. Costs of carnivory in the common bladderwort, Utricularia macrorhiza.Oecologia 89: 348-355.

Knight, S. E. and Frost, T. M. 1991. Bladder control in Utricularia macrorhiza: lake-specific variation in plant investment in carnivory. - Ecology 72: 728-734.

Kosiba, P. 1992a. Studies on the ecology of Utricularia vulgaris L. I. Ecological differentation of Utricularia vulgaris L. population affected by chemical factors of the habitat. - Ekol. Pol. 40: 147-192.

Kosiba, P. 1992b. Studies on the ecology of Utricularia vulgaris L. II. Physical, chemical, and biotic factors and the growth of Utricularia vulgaris L. in cultures in vitro. - Ekol. Pol. 40: 193-212.

Kosiba, P. 1993. Ecological characteristics of the population of Utricularia ochroleuca Hartman and Utricularia neglecta Lehmann as well as their conditions of occurrence in Wegliniec [in Polish]. - Acta Univ. Wrat. (Wroclaw), Prace Bot. 52: 25-31. 
Kosiba, P. and Sarosiek, J. 1989. The site of Utricularia intermedia Hayne and Utricularia minor L. in Sztrybnica near Tarnowskie Góry [in Polish]. - Acta Univ. Wrat. (Wroclaw), Prace Bot. 38: 71-78.

673 Lambers, H., Chapin, F. S., III and Pons, T. L. 1998. Plant physiological ecology. - SpringerVerlag.

Leishman, M. R. 1999. How well do plant traits correlate with establishment ability? Evidence from a study of 16 calcareous grassland species. - New Phytol. 141: 487-496.

Lenormand, T., Roze, D. and Rousset, F. 2009. Stochasticity in evolution. - Trends Ecol. Evol. 24: $157-165$.

Lloyd, F. E. 1942. The carnivorous plants. - Ronald Press.

680 Lollar, A. Q., Coleman, D. C. and Boyd, C. E. 1971. Carnivorous pathway of phosphorus uptake by Utricularia inflata. - Arch. Hydrobiol. 69: 400-404.

682 Lowrie, A. 1998. Canrivorous plants of Australia, Volume 3. - Univ. Western Australia Press.

683 Maberly, S. C. and Madsen, T. V. 2002. Freshwater angiosperm carbon concentrating mechanisms: processes and patterns. - Funct. Plant Biol. 29: 393-405.

685 Maberly, S. C. and Spence, D. H. N. 1983. Photosynthetic inorganic carbon use by freshwater plants. - J. Ecol. 71: 705-724.

687 Madsen, J. D., Hartleb, C. F. and Boylen, C. W. 1991. Photosynthetic characteristics of Myriophyllum spicatum and six submersed aquatic macrophyte species native to Lake George, New York. - Freshwater Biol. 26: 233-240.

690

Madsen, T. V. and Brix, H. 1997. Growth, photosynthesis and acclimation by two submerged macrophytes in relation to temperature. - Oecologia 110: 320-327. 
692 Madsen, T. V., Maberly, S. C. and Bowes, G. 1996. Photosynthetic acclimation of submersed 693 angiosperms to $\mathrm{CO}_{2}$ and $\mathrm{HCO}_{3}{ }^{-}$- - Aquat. Bot. 53: 15-30.

694 Marañón, T. and Grubb, P. J. 1993. Physiological basis and ecological significance of the seed 695 size and relative growth rate relationship in Mediterranean annuals. - Func. Ecol. 7: 591599.

697 Méndez, M. and Karlsson, P. S. 1999. Costs and benefits of carnivory in plants: insights from the photosynthetic performance of four carnivorous plants in a subarctic environment. -

$699 \quad$ Oikos 86: 105-112.

700 Moeller, R. E. 1980. The temperature-determined growing season of a submerged hydrophyte: tissue chemistry and biomass turnover of Utricularia purpurea. - Freshwater Biol. 10:

Moon, D. C., Rossi, A. M., Depaz, J., McKelvey, L., Elias, S., Wheeler, E. and Moon, J. 2010. Ants provide nutritional and defensive benefits to the carnivorous plant Sarracenia minor. - Oecologia 164: 185-192.

Nielsen, R. 2009. Adaptionism - 30 years after Gould and Lewontin. - Evolution 63: 2487-2490.

707 Nielsen, S. L. and Sand-Jensen, K. 1989. Regulation of photosynthetic rates of submerged rooted 708 macrophytes. - Oecologia 81: 364-368.

709 Nielsen, S. L. and Sand-Jensen, K. 1991. Variation in growth rates of submerged rooted 710 macrophytes. - Aquat. Bot. 39: 109-120.

711 Olde Venterink, H., Wassen, M. J., Verkroost, A. W. M. and De Ruiter, P. C. 2003. Species 712 richness-productivity patterns differ between N-, P-, and K-limited wetlands. - Ecology $713 \quad 84: 2191-2199$. 
714 Ordoñez, J. C., van Bodegom, P. M., Witte, J.-P. M., Wright, I. J., Reich, P. B. and Aerts, R.

715 2009. A global study of relationships between leaf traits, climate and soil measures of

716 nutrient fertility. - Global Ecol. Biogeogr. 18: 137-149.

717 Osunkoya, O. O., Daud, S. D., Di-Giusto, B., Wimmer, F. L. and Holige, T. M. 2007.

718 Construction costs and physico-chemical properties of the assimilatory organs of

719 Nepenthes species in northern Borneo. - Ann. Bot. 99: 895-906.

720 Osunkoya, O. O., Daud, S. D. and Wimmer, F. L. 2008. Longevity, lignin content and construction cost of the assimilatory organs of Nepenthes species. - Ann. Bot. 102: 845-

723 Pagano, A. M. and Titus, J. E. 2004. Submersed macrophyte growth at low pH: contrasting responses of three species to dissolved inorganic carbon enrichment and sediment type.Aquat. Bot. 79: 65-74.

Pagano, A. M. and Titus, J. E. 2007. Submersed macrophyte growth at low pH: carbon source influences response to dissolved inorganic carbon enrichment. - Freshwater Biol. 52:

729 Pavlovič, A., Masarovičová, E. and Hudák, J. 2007. Carnivorous syndrome in Asian pitcher plants of the genus Nepenthes. - Ann. Bot. 100: 527-537.

731 Pavlovič, A., Singerová, L., Demko, V. and Hudák, J. 2009. Feeding enhances photosynthetic efficiency in the carnivorous pitcher plant Nepenthes talangensis. - Ann. Bot. 104: 307-

734 Pavlovič, A., Singerová, L., Demko, V., Šantrůček, J. and Hudák, J. 2010. Root nutrient uptake enhances photosynthetic assimilation in prey-deprived carnivorous pitcher plant Nepenthes talangensis. - Photosynthetica 48: 227-233. 
737 Pierini, S. A. and Thomaz, S. M. 2004. Effects of inorganic carbon source on photosynthetic 738 rates of Egeria najas Planchon and Egeria densa Planchon (Hydrocharitaceae). - Aquat. $739 \quad$ Bot. 78: 135-146.

740 Plummer, G. and Kethley, J. B. 1964. Foliar absorption of amino acids, peptides, and other 741 nutrients by the pitcher plant, Sarracenia flava. - Bot. Gaz. 125: 245-260.

742 Poorter, H. and Remkes, C. 1990. Leaf area ratio and net assimilation rate of 24 wild species 743 differing in relative growth rate. - Oecologia 83: 553-559.

744 Raven, J. A., Handley, L. L. and Andrews, M. 2004. Global aspects of C/N interactions 745 determining plant-environment interactions. - J. Exp. Bot. 55: 11-25.

746 Rees, M., Osborne, C. P., Woodward, F. I., Hulme, S. P., Turnbull, L. A. and Taylor, S. H. 2010.

747 Partitioning the components of relative growth rate: how important is plant size $748 \quad$ variation? - Am. Nat. 176: E152-E161.

749 Reich, P. B., Oleksyn, J. and Wright, I. J. 2009. Leaf phosphorus influences the photosynthesis750 nitrogen relation: a cross-biome analysis of 314 species. - Oecologia 160: 207-212.

751 Reich, P. B., Wright, I. J. and Lusk, C. H. 2007. Predicting leaf physiology from simple plant 752 and climate attributes: a global GLOPNET analysis. - Ecol. Appl. 17: 1982-1988.

753 Rose, K. E., Atkinson, R. L., Turnbull, L. A. and Rees, M. 2009. The costs and benefits of fast $754 \quad$ living. - Ecol. Lett. 12: 1379-1384.

755 Sand-Jensen, K. 1989. Environmental variables and their effect on photosynthesis of aquatic 756 plant communities. - Aquat. Bot. 34: 5-25.

757 Sand-Jensen, K. and Frost-Christensen, H. 1998. Photosynthesis of amphibious and obligately 758 submerged plants in $\mathrm{CO}_{2}$-rich lowland streams. - Oecologia 117: 31-39. 
Santiago, L. S. and Wright, S. J. 2007. Leaf functional traits of tropical forest plants in relation to growth form. - Func. Ecol. 21: 19-27.

Shipley, B. 2002. Trade-offs between net assimilation rate and specific leaf area in determining relative growth rate: relationship with daily irradiance. - Func. Ecol. 16: 682-689.

763 Shipley, B., Lechowicz, M. J., Wright, I. and Reich, P. B. 2006. Fundamental trade-offs generating the worldwide leaf economics spectrum. - Ecology 87: 535-541.

765 Shipley, B. and Peters, R. H. 1990. A test of the Tilman model of plant strategies: relative growth rate and biomass partitioning. - Am. Nat. 136: 139-153.

767 Sirová, D., Borovec, J., Černá, B., Rejmánková, E., Adamec, L. and Vrba, J. 2009. Microbial community development in the traps of aquatic Utricularia species. - Aquat. Bot. 90:

770 Sirová, D., Borovec, J., Šantrůčková, H., Šantrůček, J., Vrba, J. and Adamec, L. 2010. Utricularia carnivory revisited: plants supply photosynthetic carbon to traps. - J. Exp. Bot. 61: 99-103.

Taylor, P. 1989. The genus Utricularia: a taxonomic monograph. - Kew Bulletin Additional Series 14 .

Titus, J. E. and Andorfer, J. H. 1996. Effects of $\mathrm{CO}_{2}$ enrichments on mineral accumulation and nitrogen relations in a submersed macrophyte. - Freshwater Biol. 36: 661-671.

Ulanowicz, R. E. 1995. Utricularia's secret: the advantage of positive feedback in oligotrophic environments. - Ecol. Modell. 79: 49-57.

Wright, I. J., Reich, P. B., Cornelissen, J. H. C., Falster, D. S., Garnier, E., Hikosaka, K., Lamont, B. B., Lee, W., Oleksyn, J., Osada, N., Poorter, H., Villar, R., Warton, D. I. and 

Westoby, M. 2005. Assessing the generality of global leaf trait relationships. - New Phytol. 166: 485-496.

783 Wright, I. J., Reich, P. B., Westoby, M., Ackerly, D. D., Baruch, Z., Bongers, F., CavenderBares, J., Chapin, T., Cornelissen, J. H. C., Diemer, M., Flexas, J., Garnier, E., Groom, P. K., Gulias, J., Hikosaka, K., Lamont, B. B., Lee, T., Lee, W., Lusk, C., Midgley, J. J., Navas, M.-L., Niinemets, U., Oleksyn, J., Osada, N., Poorter, H., Poot, P., Prior, L., Pyankov, V., Roumet, C., Thomas, S. C., Tjoelker, M. G., Veneklaas, E. J. and Villar, R. 2004. The worldwide leaf economics spectrum. - Nature 428: 821-827. 


\section{Figure Legends}

791 Figure 1. Relative growth rates (RGR: $\mathrm{g} \mathrm{g}^{-1} \mathrm{~d}^{-1}$ ) for a wide variety of herbaceous plants. Boxes

792 illustrate median RGR (center horizontal line), upper and lower quartiles (limits of grey boxes),

793 upper and lower deciles (horizontal lines delimiting ends of vertical lines), and individual

794 observations beyond the upper and lower deciles (solid circles). Box width is proportional to

795 sample size, and ranges from $N=2$ (for aquatic unrooted herbs exclusive of ACPs) to $N=208$

796 (for herbaceous dicotyledonous angiosperms, exclusive of TCPs). Data compiled from Grime

797 and Hunt (1975), Fenner (1983), Eissenstat and Caldwell (1987), Poorter and Remkes (1990),

798 Shipley and Peters (1990), Nielsen and Sand-Jensen (1991), Marañón and Grubb (1993), Hunt

799 and Cornelissen (1997), Keddy et al. (1998), Adamec (1999; 2000; 2002; 2008b; 2010a),

800 Adamec and Lev (1999), Leishman (1999), Shipley (2002), Pagano and Titus (2004; 2007), and

801 Farnsworth and Ellison (2008). The full dataset is available from the Harvard Forest Data

802 Archive (http://harvardforest.fas.harvard.edu/data/archive.html), Dataset HF-168.

803

804 Figure 2. Maximum dry mass-based photosynthetic rates $\left(\right.$ nmol $\mathrm{CO}_{2}$ fixed $\left.\mathrm{g}^{-1} \mathrm{~s}^{-1}\right)$ for leaves or 805 shoots of herbaceous plants. Boxes as in Fig. 1; box width is proportional to sample size, and 806 ranges from $N=8$ (for aquatic unrooted herbs exclusive of ACPs) to $N=141$ (for herbaceous 807 dicotyledonous angiosperms, exclusive of TCPs). Data for terrestrial plants are from Ellison 808 (2006), Pavlovič et al. (2007; 2009; 2010), Farnsworth and Ellison (2008), Karagatzides and 809 Ellison (2009), Hájek and Adamec (2010) and Bruzzese et al. (2010). Data for aquatic plants are 810 from Boston et al. (1989), Nielsen and Sand-Jensen (1989), Madsen et al. (1991, 1996), Madsen 811 and Brix (1997), Adamec (1997b; 2006; 2008c), Maberly and Madsen (2002), Kahara and 812 Vermaat (2003), Pierini and Thomaz (2004), and Klavsen and Maberly (2010). The full dataset 
813 is available from the Harvard Forest Data Archive

814 (http://harvardforest.fas.harvard.edu/data/archive.html), Dataset HF-168.

816 Figure 3. Mass-based dark respiration and photosynthetic rates $\left(\mathrm{nmol} \mathrm{CO}_{2} \mathrm{~g}_{-}{ }^{1} \mathrm{~s}^{-1}\right)$ for

817 carnivorous plants for which both were measured on the same plants. Different symbols are used

818 for different genera. Colors represent types of carnivorous plants: blue - aquatic carnivorous

819 plants (ACPs: Aldrovanda and Utricularia); dark green - terrestrial carnivorous plants (TCPs)

820 with separate traps and lamina (Nepenthes, Dionaea) or phyllodia (Sarracenia); light green with

821 black border - TCPs without separate traps and lamina (Drosera, Drosophyllum, Pinguicula).

822 Solid symbols are leaves, lamina, phyllodia, or entire plants, as appropriate; open symbols are

823 traps measured separately of Utricularia, Nepenthes, and Sarracenia. Solid symbols with a

824 central cross are for Aldrovanda, Utricularia, and Nepenthes that had received supplemental

825 prey or nutrients. Data compiled from Knight (1992), Adamec (1997b; 2008c), Mendéz and

826 Karlsson (1999), Pavlovič et al. (2007; 2009; 2010); Bruzzese et al. (2010), and Hájek and

827 Adamec (2010). Regression lines are shown for all TCPs (green line) and ACPs (blue line). The

828 full dataset is available from the Harvard Forest Data Archive

829 (http://harvardforest.fas.harvard.edu/data/archive.html), Dataset HF-168.

831 Figure 4. Tissue nutrient content of nitrogen $(\mathrm{N})$, phosphorus $(\mathrm{P})$, and potassium $(\mathrm{K})$ in leaves or

832 shoots of aquatic (ACP) and terrestrial (TCP) carnivorous plants. Box plots as in Fig. 1, but not

833 scaled to sample size, which is given in axis labels. The vertical blue lines indicate the value

834 below which the nutrient is considered to limit plant growth. Data for TCPs are from Ellison

835 (2006), Osunkoya et al. (2007) Pavlovič et al. (2007; 2009; 2010), Farnsworth and Ellison 
836 (2008), Karagatzides and Ellison (2009), Karagatzides et al. (2009), Adamec (2009a), and Moon

837 et al. (2010). Data for ACPs are from Moeller (1980), Kamiński (1987a; 1987b), Kosiba and

838 Sarosiek (1989), Kosiba (1992a; 1992b; 1993), Friday and Quarmby (1994), Bern (1997), and

839 Adamec $(2000 ; 2008 \mathrm{a} ; 2010 \mathrm{~b})$. The full dataset is available from the Harvard Forest Data

840 Archive (http://harvardforest.fas.harvard.edu/data/archive.html), Dataset HF-168.

842 Figure 5. Stoichiometric relationships for ACPs (blue) and TCPs (green) in which N, P, and K

843 all were measured simultaneously on the same individual. Solid symbols indicate entire plants or

844 traps; open symbols indicate laminae measured separately on Nepenthes. "Sarraceniaceae"

845 includes both Sarracenia and Darlingtonia. Dark lines indicate regions of N, P or P+N, and K or

$846 \mathrm{~K}+\mathrm{N}$ limitation following the criteria of Olde-Venterink (2003). Data sources as in Fig. 4. The

847 full dataset is available from the Harvard Forest Data Archive

848 (http://harvardforest.fas.harvard.edu/data/archive.html), Dataset HF-168. 


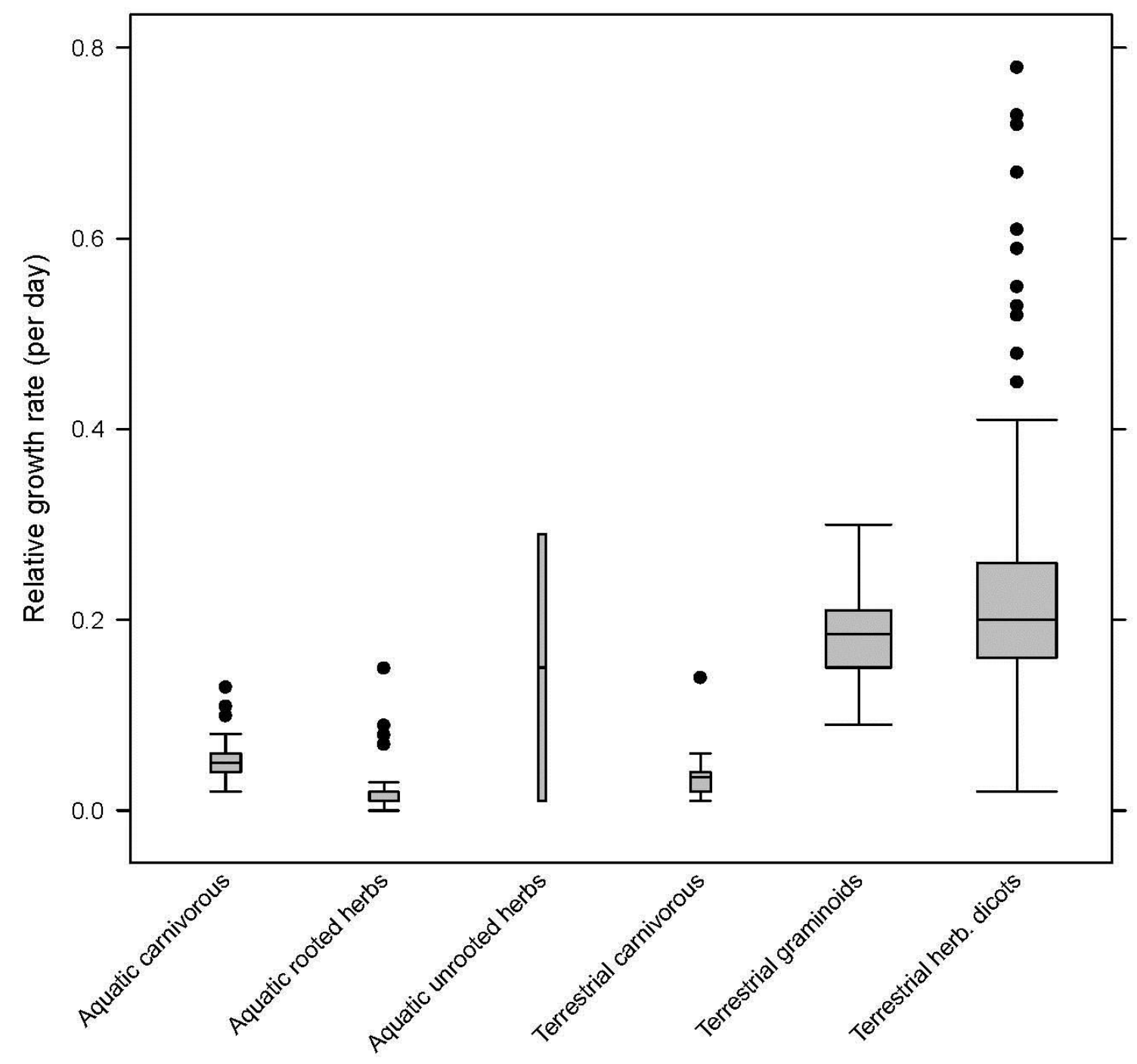

850

851

Figure 1

852 


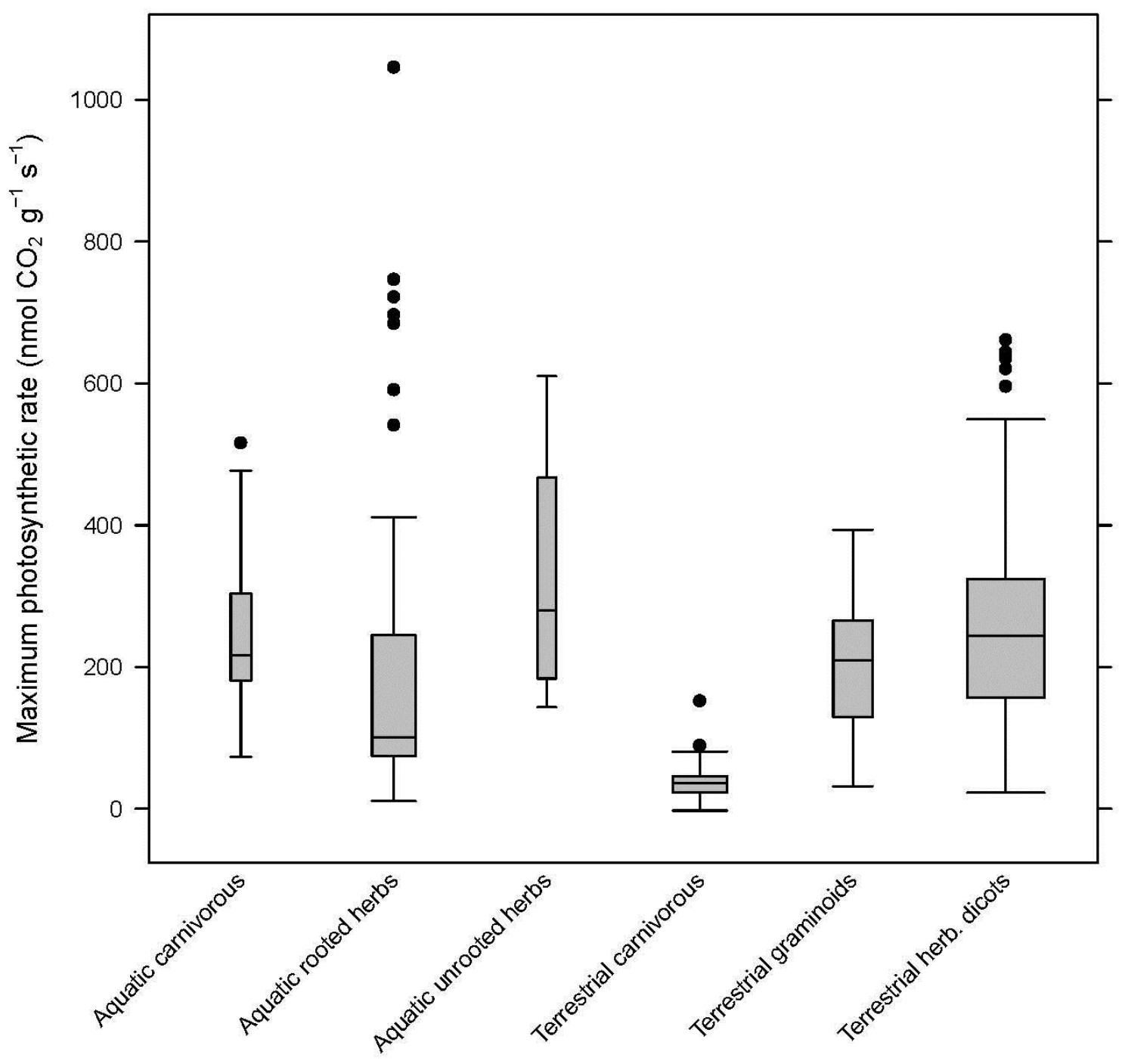

853

854

Figure 2

855 


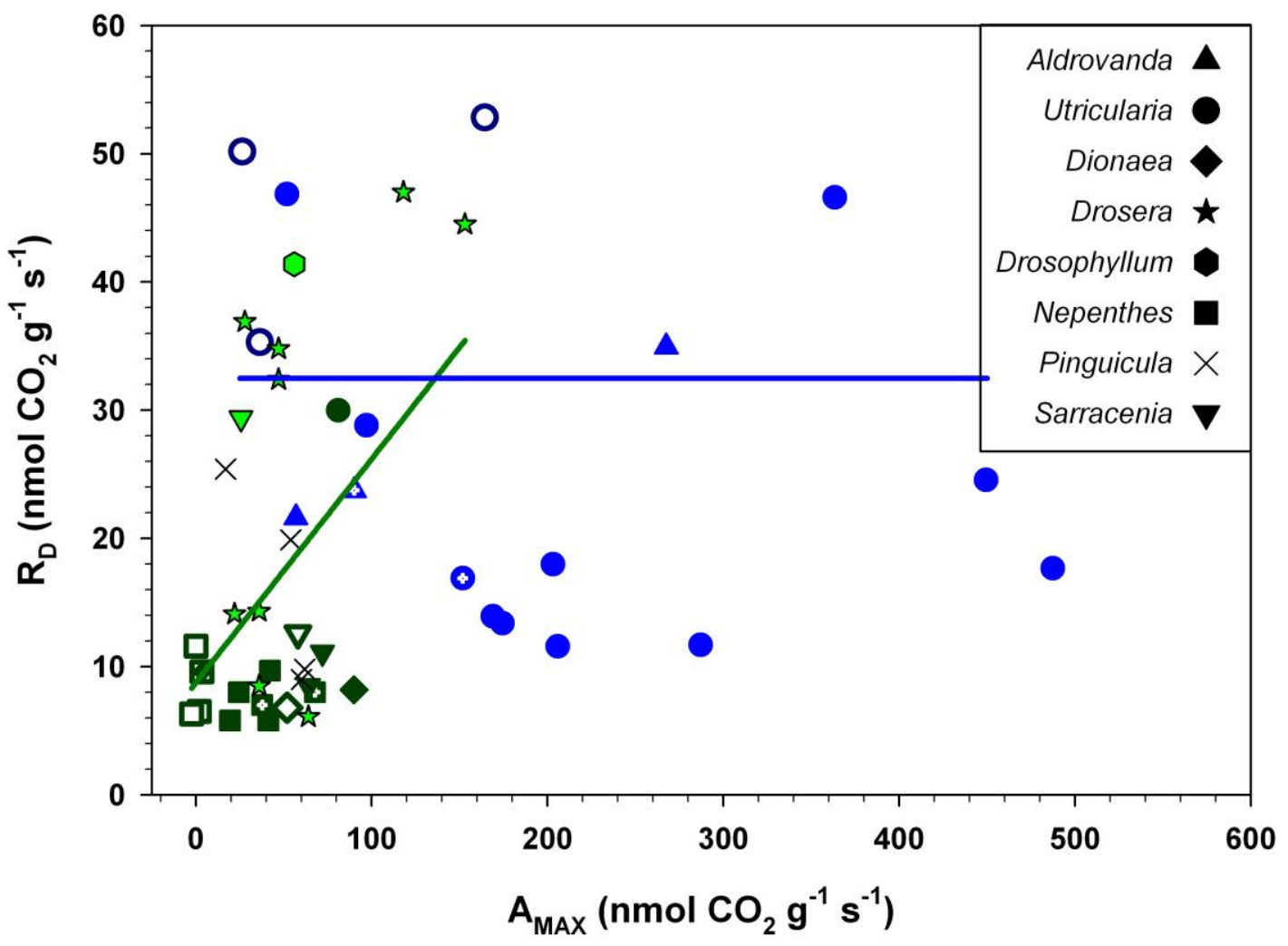

856

Figure 3

858 

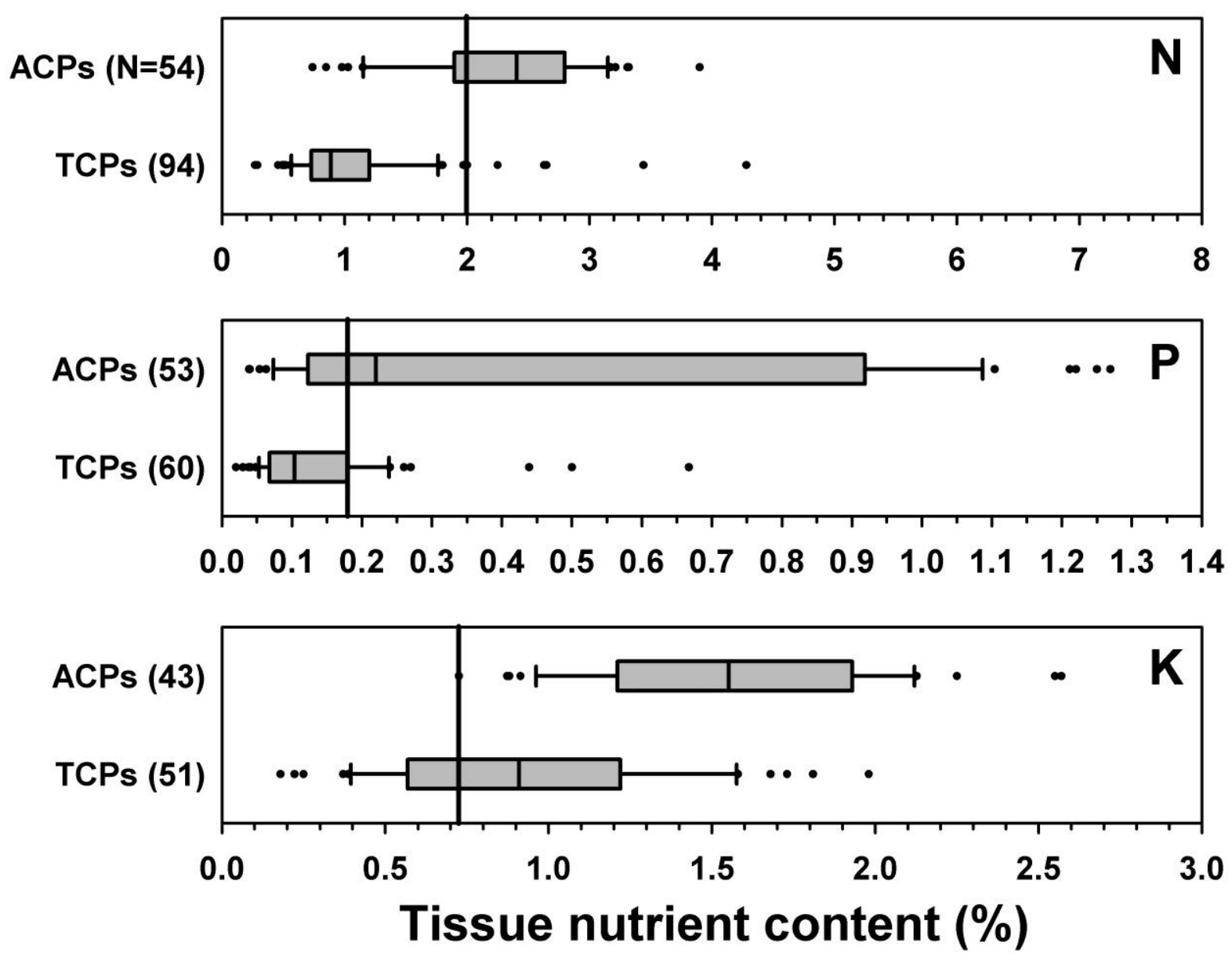

861

Figure 4

862 


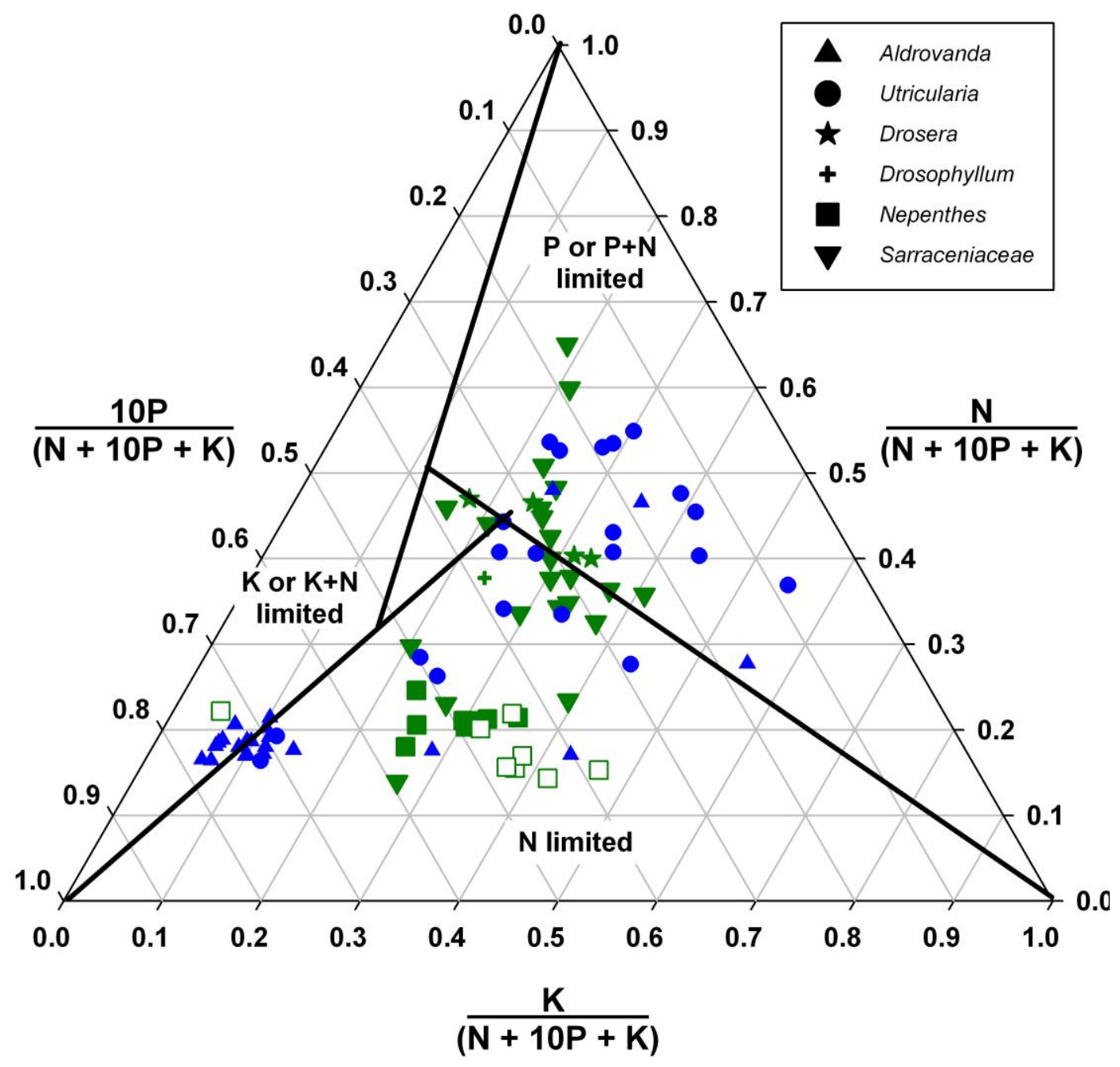

864

865

Figure 5

866 